UDC 614.72:616.8

DOI: $10.21668 /$ health.risk/2020.3.02.eng

Short essay

\title{
STROKE AND AIR POLLUTION. A WORLDWIDE PUBLIC HEALTH PROBLEM
}

\author{
M. Giroud ${ }^{1}$, J. Reis ${ }^{2}$ \\ ${ }^{1}$ University Hospital of Dijon, 2 Boulevard du Maréchal de Lattre de Tassigny, 21000, Dijon, France \\ ${ }^{2}$ University of Strasbourg, 3 rue du loir, Oberhausbergen, Strasbourg, 67205, France
}

After myocardial infarction, stroke is now associated with air pollution.

From local data and literature, we report the strength of the association between air pollution and stroke. We try to understand the biological mechanisms between exposure to air pollutants and stroke risk.

The association between air pollution and stroke is strong, confirmed and real. Air pollution and small particulate matter are the most toxic. Patients with classical neuro-vascular risk factors or a history of stroke or transient ischemic attack are at risk of stroke induced by air pollution.

Air pollution is a serious modifiable risk factor for stroke and a silent killer inducing stroke. This new neuro-vascular risk factor is useful for public health policies.

Key words: ischaemic stroke, hemorrhagic stroke, stroke, air pollution, air pollutants.

The relationships between air pollution and stroke are now well known and may be introduced in public health policy [1].

We propose to review the data from literature and personal data.

Air pollution. Air pollution is a complex association of air pollutants induced by different sources [2].

Air pollution is the product of small particulate matter $(\mathrm{PM})$ and gaseous pollution with sulfur dioxide $\left(\mathrm{SO}_{2}\right)$, ozone $\left(\mathrm{O}_{3}\right)$, nitrogen dioxide $\left(\mathrm{NO}_{2}\right)$ and carbon monoxide $(\mathrm{CO})$. $\mathrm{PM}_{2.5}$ represent close to $70 \%$ of $\mathrm{PM}$ measuring less than $10 \mu \mathrm{m}\left(\mathrm{PM}_{10}\right)$ [3].

Combustion of fossil products, as well as road traffic, industrial and home heating using coal, oil or wood, mainly produces PM and $\mathrm{SO}_{2}$. Diesel engines produce high levels of nanoparticles, $\mathrm{NO}_{2}$ and $\mathrm{CO}$, while $\mathrm{O}_{3}$ is produced by photochemical reactions [4].

Stroke and air pollution: clinical data.

Results and discussion.

Thanks to cohort studies, ecological studies, meta-analyses, case-crossover studies and big data, we can summarize the following evidence-based data [5-15]:

$-\mathrm{NO}_{2}$ and $\mathrm{PM}$ are associated to hospitalization from stroke induced by long-term exposure to air pollution $[5,6]$;

- Stroke risk is associated to the rise of PM2.5 levels [7];

- Residential proximity to major roadway is associated with a higher risk of ischemic stroke [5];

- The rise of $\mathrm{PM}_{2.5}$ levels is associated with the rise of both ischemic and hemorrhage stroke mortality [9];

We have demonstrated the association between ischemic stroke and the number of vascular risk factors (hypertension, tobacco, hypercholesterolemia and diabetes) [13]; the role of $\mathrm{SO}_{2}, \mathrm{Co}$ and $\mathrm{NO}_{2}$ [12] is also demonstrated, as well as $\mathrm{PM}_{10}$ [11]; the place of air pollution in stroke onset is very important: $33.7 \%$ in low- and middle-income countries, $30 \%$ in high-income countries [15].

Mechanisms of action of air pollution:

Several mechanisms are well known:

(c) Giroud M., Reis J., 2020

Maurice Giroud - Chief of Neurology Department, Professor of Medicine (e-mail: maurice.giroud@chu-dijon.fr; tel.: +33 3802930 31; ORCID: https://orcid.org/0000-0002-0718-8523).

Jacques Reis - Associate Professor (jacques.reis@wanadoo.fr; tel.: +33 3688500 00; ORCID: https://orcid.org/00000003-1216-46627205). 
- translocation of nanoparticles able to cross the alveolar [16];

- capillary barriers towards the circulation [16];

- inflammation of endothelial cells [17];

- increase of endothelial cell permeability [18];

- autonomic dysfunction [1];

- atrial fibrillation [19];

- epigenetic mechanisms, acting on endothelial stem and progenitor cell functions and promoting DNA methylation [20].

\section{Clinical impact.}

Thanks to these data, we can identify people at risk (hypertension, diabetes, tobacco), children and elderly $[1,13]$.
Greater exposure to air pollution in patients having previous neuro-cardio-vascular risk factors is strongly associated with a greater risk of stroke and also myocardial infarction [1, 14].

Therefore, we provide tools to conduct a specific public health policy towards this new problem.

Conclusion. A new modifiable risk factor for stroke is present in the air, after analysis of epidemiological studies. New basic mechanisms suggest urgent effective strategy from public health policy.

Funding. The research was not granted any sponsor support.

Conflict of interests. The authors declare there is no any conflict of interests.

\section{References}

1. Graber M., Mohr S., Baptiste L., Duloquin G., Blanc-Labarre C., Mariet A.S., Giroud M., Béjot Y. Air pollution and stroke. A new modifiable risk factor is in the air. Revue Neurologique, 2019, vol. 175, no. 10, pp. 619-624. DOI: 10.1016/j.neurol.2019.03.003

2. Lee K.K., Miller M.R., Shah A.D. Air pollution and stroke. Journal of Stroke, 2018, vol. 20, no. 1 , pp. 2-11. DOI: $10.5853 /$ jos.2017.02894

3. Maheswaran R. Air pollution and stroke. An overview of the evidence base. Spatiotemporal Epidemiol, 2016, no. 18, pp. 74-81. DOI: 10.1016/j.sste.2016.04.004

4. Cassee F.R., Heroux M.E., Gerlofs-Nijland M.E., Kelly F.J. Particulate matter beyond mass: recent health evidence on the role of fractions, chemical constituent and sources of emission. Inhal Toxicol, 2013, no. 25, pp. 802-812. DOI: 10.3109/08958378.2013.850127

5. Ljungman P.L., Mittleman M.A. Ambient air pollution and stroke. Stroke, 2014, no. 45, pp. 3734-3441. DOI: 10.1161/STROKEAHA.114.003130

6. Scheers H., Jacobs L., Casas I., Nemery B., Nawrot T.S. Long-term exposure to particulate matter air pollution is a risk factor for stroke: meta-analytical evidence. Stroke, 2015, vol. 46, pp. 3058-2066. DOI: 10.1161/STROKEAHA.115.009913

7. Kulick E.R., Wellenius G.A., Boehme A.K., Sacco R.L., Elkind M.S. Residential proximity to major roadways and risk of incident ischemic stroke in NOMAS (The Northern Manhattan Study). Stroke, 2018, vol. 49, pp. 835-841. DOI: 10.1161/STROKEAHA.117.019580

8. Maheswaran R., Pearson T., Smeeton N.C., Beevers S.D., Campbell M.J., Wolfe C.D. Impact of outdoor air pollution on survival after stroke: population-based cohort study. Stroke, 2010, vol. 41, pp. 869-877. DOI: 10.1161/STROKEAHA.109.567743

9. Zhang R., Liu G., Jiang Y., Li G., Pan Y., Wang Y., Wei Z., Wang J., Wang Y. Acute effects of particulate air pollution on ischemic stroke and hemorrhagic stroke mortality. Frontiers in Neurology, 2018, no. 9, pp. 827. DOI: 10.3389/fneur.2018.00827

10. Yang W.S., Wang X., Deng Q., Fan W.-Y., Wang W.-Y. An evidence-based appraisal of global association between air pollution and risk of stroke. Int. J. Cardiol, 2014, vol. 175, no. 2, pp. 307-313. DOI: 10.1016/j.ijcard.2014.05.044

11. Shah A.S., Lee K.K., McAllister D.A., Hunter A., Nair H., Whiteley W., Langrish J.P., Newby D.E. [et al.]. Short term exposure to air pollution and stroke: systematic review and metaanalysis. BMJ, 2015, vol. 350, pp. h1295. DOI: 10.1136/bmj.h1295

12. Wang Y., Eliot N., Wellenius G.A. Short-term changes in ambient particulate matter and risk of stroke: a systematic review and meta-analyses. J. Am. Heart. Assoc, 2014, no. 3, pp. e00093. DOI: 10.1161/JAHA.114.000983 
13. Henrotin J.B., Besancenot J.P., Bejot Y., Giroud M. Short-term effects of ozone air pollution on ischemic stroke occurrence: a case-crossover analysis from a 10-year population-based study in Dijon, France. Occup. Environ. Med., 2007, no. 64, pp. 439-445. DOI: 10.1136/oem.2006.029306

14. Maheswaran K., Pearson T., Beevers S.D., Campbell M.J., Wolfe C.D. Air pollution and subtypes, severity and vulnerability to ischemic stroke. A population-based case-crossover study. PLoS One, 2016, no. 11, pp. e0158556. DOI: 10.1371/journal.pone.0158556

15. Feigin V.L., Roth G.A., Nathavi M., Parmar P., Krishanamurthi R., Chugh S., Mensah G.A., N. Bo [et al.]. Global Burden of stroke and risk factors in 188 countries, during 1990-2013: a systematic analysis for the Global Burden of Disease Study 2013. Lancet Neurol., 2016, vol. 15, pp. 913-924. DOI: 10.1016/S1474-4422(16)30073-4

16. Oberdörster G., Sharp Z., Atudorei V., Elder A., Gelein R., Lunts A., Kreyling W., Cox C. [et al.]. Extrapulmonary translocation of ultrafine carbon particles following whole-body inhalation exposure of rats. J. Toxicol. Environ. Health A., 2002, no. 65, pp. 1531-1543. DOI: 10.1080/00984100290071658

17. Aung H.H., Lame M.W., Gohil K., He G., Denison M.S., Rutledge J.C., Wilson D.V. Comparative gene responses to collected ambient particles in vitro: endothelial responses. Physiol. Genomics, 2011, vol. 43, no. 15, pp. 917-929. DOI: 10.1152/physiolgenomics.00051.2011

18. Chao M.W., Kozlosky J., Po I.P., Strickland P.O., Svoboda K.K., Cooper K., Laumbach R.J., Gordon M.K. Diesel exhaust particle exposure causes redistribution of endothelial tube VE-cadherin. Toxicology, 2011, vol. 279, pp. 73-84. DOI: 10.1016/j.tox.2010.09.011

19. Chung J.W., Bang O.Y., Ahn K., Park S.S., Park T.H., Kim J.G., Ko Y., Lee S. [et al.]. Air pollution is associated with ischemic stroke via cardiogenic embolism. Stroke, 2017, vol. 48, no. 1, pp. 17-23. DOI: 10.1161/STROKEAHA.116.015428

20. Fraineau S., Palii C.G., Allan D.S., Brand M. Epigenetic regulation of endothelial-cell-mediated vascular repair. FEBS Journal, 2015, vol. 282, no. 9, pp. 1605-1629. DOI: 10.1111/febs.13183

Giroud M., Reis J. Stroke and air pollution. a worldwide public health problem. Health Risk Analysis, 2020, no. 3, pp. 19-21. DOI: 10.21668/health.risk/2020.3.02.eng

Received: 16.04 .2020

Accepted: 18.08 .2020

Published: 30.09.2020 